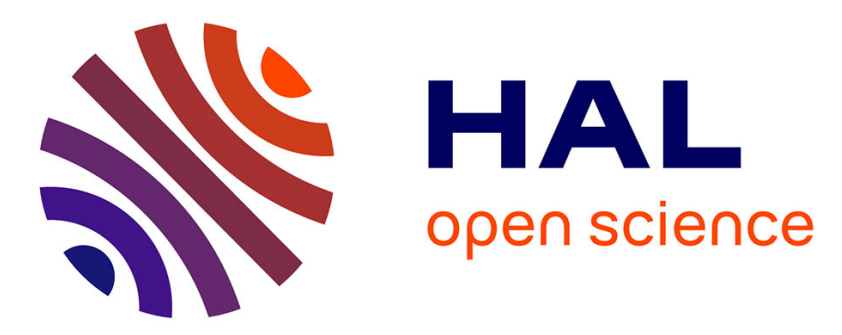

\title{
Cocrystallization through the use of a salt: The case of thiourea with a new propanediammonium oxalate salt
} Antoine Blaise Kama, Erwann Jeanneau, Mamadou Sidibe, Cheikh A.K. Diop, Romain Gautier

\section{- To cite this version:}

Antoine Blaise Kama, Erwann Jeanneau, Mamadou Sidibe, Cheikh A.K. Diop, Romain Gautier. Cocrystallization through the use of a salt: The case of thiourea with a new propanediammonium oxalate salt. Journal of Crystal Growth, 2019, 528, pp.125267. 10.1016/j.jcrysgro.2019.125267 . hal02376233

\section{HAL Id: hal-02376233 \\ https://hal.science/hal-02376233}

Submitted on 25 Nov 2020

HAL is a multi-disciplinary open access archive for the deposit and dissemination of scientific research documents, whether they are published or not. The documents may come from teaching and research institutions in France or abroad, or from public or private research centers.
L'archive ouverte pluridisciplinaire HAL, est destinée au dépôt et à la diffusion de documents scientifiques de niveau recherche, publiés ou non, émanant des établissements d'enseignement et de recherche français ou étrangers, des laboratoires publics ou privés. 


\author{
Antoine Blaise Kama ${ }^{a, b,{ }^{* *}}$, Erwann Jeanneauc, Mamadou Sidibe ${ }^{a}$, Cheikh A. K Diop ${ }^{\text {, }}$ \\ Romain Gautier ${ }^{\mathrm{b}, ~ *}$

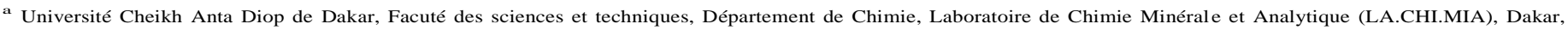 \\ Sénégal.
${ }^{b}$ Institut des Materiaux Jean Rouxel (IMN), Université de Nantes, CNRS, 2 rue de la Houssinière,BP 32229, 44322 Nantes cedex 3, France.

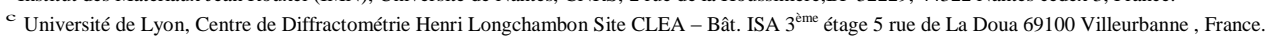

\begin{tabular}{|c|c|}
\hline ARTICLE INFO & ABSTRACT \\
\hline $\begin{array}{l}\text { Keywords: } \\
\text { Thiourea } \\
\text { Hydrogen bonds } \\
\text { Pholuminescence } \\
\text { X-ray diffraction }\end{array}$ & $\begin{array}{l}\text { A new blue photoluminescent 3D supramolecular salt namely } 1,3 \text { propanediammonium oxalate has been synthesized and } \\
\text { characterized by FT-IR spectroscopy and powder/single crystal X-ray diffraction. The incorporation of the environmental } \\
\text { harmful thiourea was investigated. Single crystals were obtained after incorporation and the X-ray diffraction revealed the } \\
\text { self-assembly of thiourea with } 1,3 \text { propanediammonium oxalate. The thiourea interacts with the salt through strong hydrogen } \\
\text { bonds. The intensity of the blue luminescence slightly decreases upon incorporation of thiourea. }\end{array}$ \\
\hline
\end{tabular}

\section{Introduction}

For the design of supramolecular organic salts, alkylammonium cations are interesting building blocks. Primary alkylammonium can create hydrogen bonds through the three hydrogen atoms therein. A counterion such as oxalate (four acceptors of hydrogen bonds) can be used with such cations and lead to supramolecular salts. Moreover, Carboxylate ions such as oxalate incorporated in film were shown early in the literature acting as luminescent centers [1-3]. Luminescent materials may be useful for photoluminescence sensing.

Photoluminescence sensing is a contact-less and non-destructive method and has been widely used for the detection of some harmful materials such as highly toxic metals or environmental pollutants [4-5]. It was also used for the recognition of small molecules/solvents by incorporating them into luminescent materials [6-9]. Photoluminescence sensing may be therefore useful for the detection of environmental harmful molecules such as thiourea.

Thiourea may be found at elevated concentrations in water or air, due to the multiple uses of this chemical in photography, dyes, drugs, flame retardants, or pesticides [10-14]. It was shown that this molecule has a very slow biodegradability [10] and elevated concentrations are toxic to human, and microorganisms [10]. Several methods have been reported for the determination of trace amounts of thiourea by Raman spectroscopy [15], spectrophotometry [16], titrimetry using iodine [17], high performance liquid chromatography (HPLC) [18] electrochemical methods etc. [19-25]. However, most of these methods have drawbacks such as instrumental

* Corresponding author.

** Corresponding author

E-mail addresses: kama.antoineblaise@yahoo.fr (A.B. Kama) ould be

Romain.Gautier@enrs-imn.fr (R. Gautier).

three-

dimensional supramolecular salt, namely 1,3 propanediammonium oxalate resulting from the mixture of low cost reagents 1,3 propanediamine and oxalic acid. We successfully incorporated the thiourea into this new luminescent salt.

\section{Experimental section}

\subsection{Materials}

Oxalic acid (99\%), 1, 3 diaminopropane (99\%), thiourea (99\%), were purchased from Sigma-Aldrich and used without further purification. Distilled water was used in the syntheses and the incorporation of thiourea.

\subsection{Synthesis of compound 1}

The synthesis was carried out at room temperature. The compound (1) $\mathrm{NH}_{3}\left(\mathrm{CH}_{2}\right)_{3} \mathrm{NH}_{3} \cdot \mathrm{C}_{2} \mathrm{O}_{4}$ (1,3 propanediammonium oxalate) was prepared by mixing 1,3 diaminopropane $(4.4 \mathrm{~g} / 59 \mathrm{mmol})$ and dihydrated oxalic acid $(7.4 \mathrm{~g} / 59 \mathrm{mmol})$ in distilled water. Evaporation at $60^{\circ} \mathrm{C}$ was carried out for one week. Colourless crystals suitable for X-ray diffraction were obtained. The synthesis diagram is presented in Fig. 1.
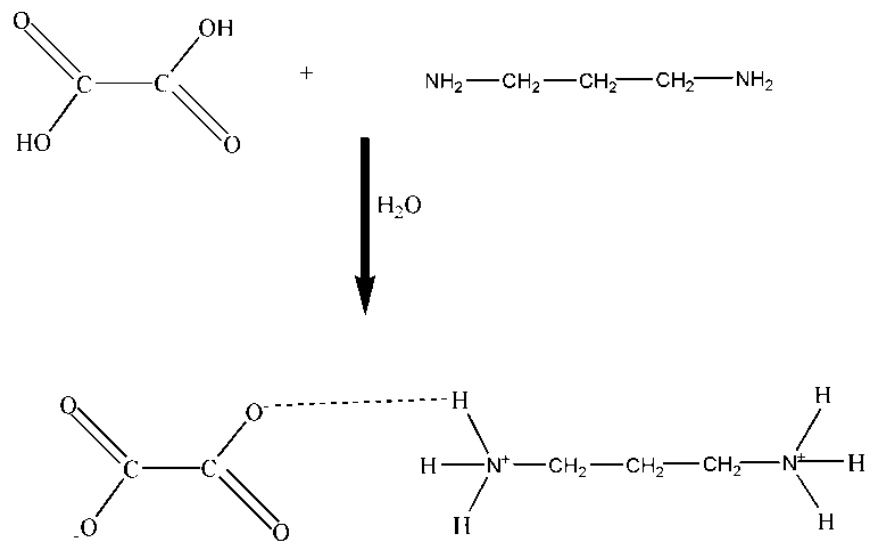

Fig 1. Synthesis diagram of compound (1) (hydrogen bonds are represented in dotted line).

\subsection{Thiourea incorporation}

The incorporation was carried out at room temperature. We mixed a portion of the previously synthetized salt (compound 1) $(0.56 \mathrm{~g} / 3 \mathrm{mmol})$ and thiourea $(0.2 \mathrm{~g} / 3 \mathrm{mmol})$ in distilled water. Evaporation at $60^{\circ} \mathrm{C}$ was carried out. After three days, colourless crystals suitable for X-ray diffraction were obtained. The synthesis diagram is presented in Fig. 2. 


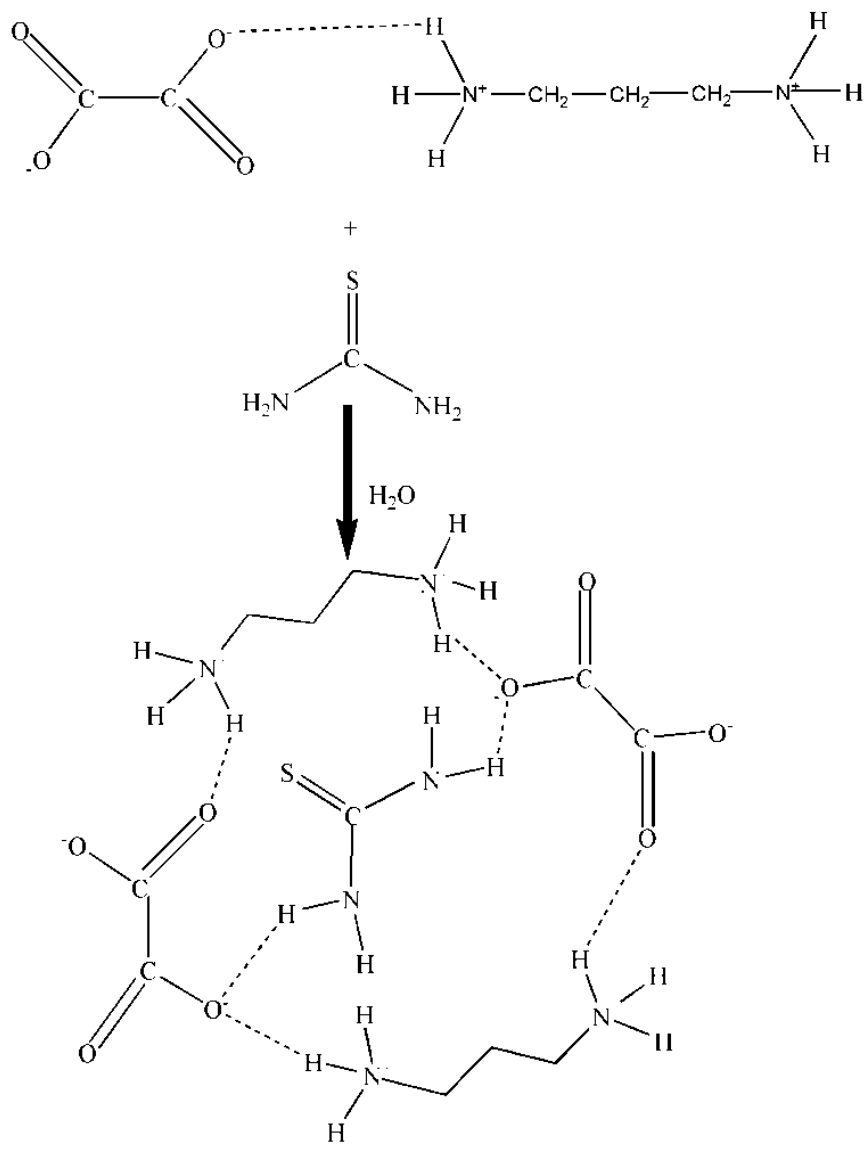

Fig. 2. Synthesis diagram of compound (2) (hydrogen bonds are represented in dotted line).

\subsection{X-ray diffraction}

Single-crystal X-ray diffraction for the two compounds was performed using an Xcalibur, Atlas, Gemini ultra diffractometer. For the refinement, in the absence of significant anomalous scattering, Friedel pairs were merged. The absolute configuration was arbitrarily assigned.

Table 1. Crystal data and structure refinement for compounds 1 and 2

\begin{tabular}{|c|c|c|}
\hline Compound & 1 & 2 \\
\hline Molecular formula & $\mathrm{C}_{2} \mathrm{O}_{4} \cdot \mathrm{C}_{3} \mathrm{H}_{12} \mathrm{~N}_{2}$ & $2\left(\mathrm{C}_{3} \mathrm{H}_{12} \mathrm{~N}_{2}\right) \cdot 2\left(\mathrm{C}_{2} \mathrm{O}_{4}\right) \cdot \mathrm{CH}_{4} \mathrm{~N}_{2} \mathrm{~S}$ \\
\hline Formula weight & 164.17 & 404.44 \\
\hline Crystal color, habit & Plate, colorless & Plate, colorless \\
\hline Dimensions, $\mathrm{mm}$ & $0.52 \times 0.37 \times 0.16$ & $0.49 \times 0.28 \times 0.11$ \\
\hline Crystal system & Orthorhombic, & Triclinic \\
\hline$a, \AA$ & $8.8036(12)$ & $6.6949(10)$ \\
\hline$b, \AA$ & $9.7527(15)$ & $8.8020(11)$ \\
\hline$c, \AA$ & $4.2015(6)$ & $16.3336(14)$ \\
\hline$\alpha, \operatorname{deg}$ & 90 & $76.600(9)$ \\
\hline$\beta, \operatorname{deg}$ & 90 & $79.085(11)$ \\
\hline$\gamma, \operatorname{deg}$ & 90 & $83.429(11)$ \\
\hline $\mathrm{V}, \AA^{3}$ & $360.74(9)$ & $916.9(2)$ \\
\hline space group & Pba2 & $P-1$ \\
\hline $\mathrm{Z}$ & 2 & 2 \\
\hline$F(000)$ & 176 & 432 \\
\hline$\theta$ range, deg & $6.5-66.7$ & $3.6-29.5$ \\
\hline $\begin{array}{l}\text { Absorption } \\
\text { coefficient, } \mathrm{mm}^{-1}\end{array}$ & 1.12 & 0.23 \\
\hline $\mathrm{T}, \mathrm{K}$ & 100 & 100 \\
\hline$\lambda, \AA$ & 1.54184 & 0.71073 \\
\hline Reflections collected & 2594 & 5938 \\
\hline $\begin{array}{l}\text { Independent } \\
\text { reflections }\end{array}$ & $638[\mathrm{R}(\mathrm{int})=0.074]$ & $4561[\mathrm{R}(\mathrm{int})=0.077]$ \\
\hline Final $\mathrm{R}$ indices & $\begin{array}{l}\mathrm{R} 1=0.041 \\
\mathrm{wR} 2=0.109\end{array}$ & $\mathrm{R} 1=0.062, \mathrm{wR} 2=0.137$ \\
\hline $\mathrm{R}$ indices (all data) & $\begin{array}{l}\mathrm{R} 1=0.0424, \quad \text { wR2 }= \\
0.113\end{array}$ & $\mathrm{R} 1=0.0849, w \mathrm{R} 2=0.187$ \\
\hline GOF on $F^{2}$ & 1.033 & 0.979 \\
\hline Peak, hole $/ \mathrm{e} \AA^{-3}$ & $-0.19,-0.33$ & $-0.96-0.66$ \\
\hline
\end{tabular}

The relatively large ratio of minimum to maximum corrections applied in the multiscan process (1: nnn) reflect changes in the illuminated volume of the crystal. Changes in illuminated volume were kept to a minimum, and were taken into account [26] by the multi-scan inter-frame scaling [27]. The $\mathrm{H}$ atoms were all located in a difference map, but those attached to carbon atoms were repositioned geometrically. The $\mathrm{H}$ atoms were initially refined with soft restraints on the bond lengths and angles to regularize their geometry $(\mathrm{C}-\mathrm{H}$ in the range $0.93-0.98, \mathrm{~N}-\mathrm{H}$ in the range $0.86-0.89 \mathrm{~N}-\mathrm{H}$ to $0.86 \mathrm{O}-\mathrm{H}=0.82 \AA$ ) and $U_{\text {iso }}\left(\mathrm{H}\right.$ ) (in the range 1.2-1.5 times $U_{\text {eq }}$ of the parent atom), after which the positions were refined with riding constraints [28].

Computing detail are the followings: Data collection: CrysAlis PRO 1.171.38.43 (Rigaku OD, 2015); cell refinement: CrysAlis PRO 1.171.38.43 (Rigaku OD, 2015); data reduction: CrysAlis PRO 1.171.38.43 (Rigaku OD, 
2015); program(s) used to solve structure: SIR97 (Altomare et al., 1999) [29]; program(s) used to refine structure: CRYSTALS (Betteridge et al., 2003) [30]; molecular graphics: CAMERON (Watkin et al., 1996) [31]; software used to prepare material for publication: CRYSTALS (Betteridge et al., 2003) [30]. The details of the crystal parameters, data collections and refinement for compound 1 and 2 are summarized in Table 1 . Selected bonds and angles for the two compounds are available in supporting information (Table S1 and S2). Details about hydrogen bonds for both compounds are listed in supporting information (Table S3 and S4).

Powder X-ray diffraction (PXRD) patterns were recorded for the salt (compound 1) with a Bruker AXS D8 diffractometer with $\mathrm{CuK} \alpha$ radiation $(\lambda$ $=1.5406 \AA$ ) at room temperature.

\subsection{Spectroscopy}

Infra-Red spectroscopy and photoluminescence measurements were carried out on compound (1). IR measurement was performed using ATR (Attenuated Total Reflectance) method [32]. PL properties were characterized by a Spex Fluorolog-3 spectrofluorometer from Jobin Yvon Instruments. Diffuse reflectance spectrum of the compound (1) was also collected with a Perkin Elmer UV-visible-NIR spectrometer (Lambda 1050) equipped with an integrating sphere.

\section{Results and discussion}

\subsection{Crystal structures}

The single-crystal X-ray diffraction performed on compound (1) reveals that it crystalizes in an orthorhombic system with space group Pba2. The asymmetric unit contains half of the anion and cation. The same measurement performed on compound (2) reveals that it crystallizes in a triclinic system with space group $P-1$. The asymmetric unit contains two units of the cation and the anion of compound (1), and one unit of thiourea.

Oxalate anion has four sites which can act as acceptor of hydrogen bonds. On the other hand, each of the two ammoniums of the 1, 3propanediammonium (PDA) has three hydrogen atoms available for hydrogen bonding. Therefore, oxalate and PDA are connected via $\mathrm{N}-\mathrm{H}^{\cdots}{ }^{\cdots} \mathrm{O}-\mathrm{C}$ strong hydrogen bonds $\left(d_{\mathrm{N}-\mathrm{H} \cdots \mathrm{O}}\right.$ is in the range of 1.9-1.95 $\AA$ ) (see supporting information table S3). Some of $\mathrm{O}$ atoms interact with two different cations through bifurcated hydrogen bonds leading to a three-dimensional network.

After mixing thiourea and the previously synthetized salt in water and after evaporation, a resulting material is formed where thiourea was completely incorporated into the supramolecular salt (Fig. 3). The two units interact via $\mathrm{N}-\mathrm{H}^{\cdots} \cdots \mathrm{O}-\mathrm{C}$ strong hydrogen bonds (see supporting information table S4: $\left.d_{\mathrm{N} 3-\mathrm{H} 31 \ldots \mathrm{O} 7}{ }^{\mathrm{i}} ; d_{\mathrm{N} 3-\mathrm{H} 32 \cdots \mathrm{O} 10} ; d_{\mathrm{N} 4-\mathrm{H} 41 \cdots \mathrm{O} 16}{ }^{\mathrm{ii}}\right)$. Crystal structure was drawn using Diamond and Mercury software.

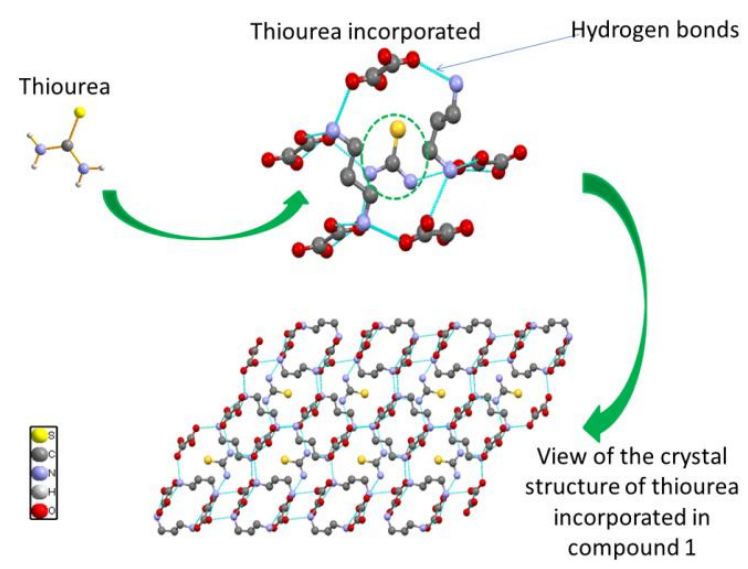

Fig. 3. Crystal structure of thiourea incorporated into supramolecular 1, 3 propanediammonium oxalate.

\subsection{Powder X-ray diffraction}

Powder X-ray diffraction shows that the salt (1) is pure. All the diffraction peaks of the powder can be indexed to the orthorhombic phase with space group Pba2 (Fig.4).

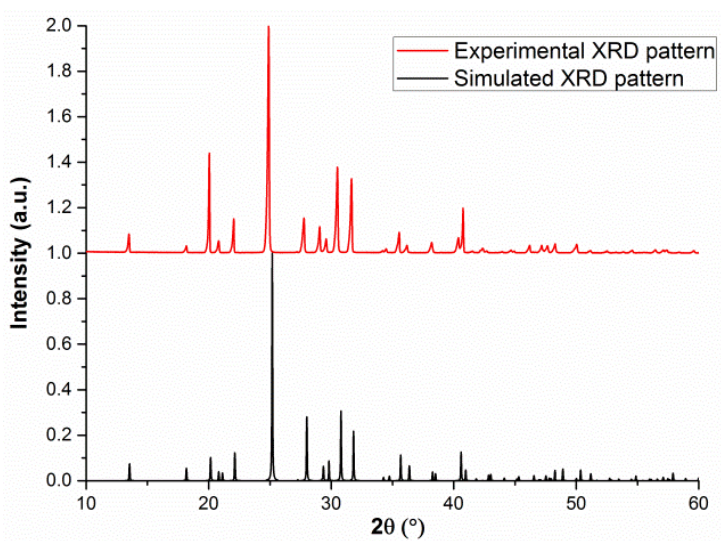

Fig. 4. Simulated (100K) and experimental (room temperature) XRD patterns of 1,3 propanediammonium oxalate.

\subsection{FT-IR spectroscopic study}

The FT-IR Spectrum of the compound (1) is shown in Fig. 5. The full attributions of the main absorption bands are listed in Table 2. According to the literature [33-36], the broad absorption band in the range of 3018-2519 $\mathrm{cm}^{-1}$ is assigned to $v \mathrm{~N}-\mathrm{H}$ vibration modes of $\mathrm{NH}_{3}$ in PDA and $v \mathrm{C}-\mathrm{H}(\mathrm{CH} 2)$ of alkyl chain. The broadness of this band is due to the strong intramolecular hydrogen bonds $\mathrm{N}-\mathrm{H}$...O as observed in the crystal structure. The vibration bands from 1631 to $1520 \mathrm{~cm}^{-1}$ are due to $\mathrm{v}_{\mathrm{as}} \mathrm{COO}^{-}$while the ones from 1293 to $1222 \mathrm{~cm}^{-1}$ are assigned to $v_{\mathrm{s}} \mathrm{COO}^{-}$. $v \mathrm{C}-\mathrm{N}$ and $\nu \mathrm{C}-\mathrm{C}$ appear respectively at 1055 and $765 \mathrm{~cm}^{-1}$. Therefore, the presence of the cation (PDA) and the anion (oxalate) is confirmed.

For the compound (2), the FT-IR spectrum is shown in Fig. 6. The full attributions of the main absorption bands are available in Table 3 [33-36]. Both spectra of compound (1) and (2) are very similar. But we can identify the presence of thiourea in addition to the cation and the anion of compound (1). Indeed the previously broad band attributed to $v \mathrm{~N}-\mathrm{H}, \mathrm{vC}-\mathrm{H}(\mathrm{CH} 2)$ shifts 
to $3274 \mathrm{~cm}^{-1}$, due to the presence of thiourea which induces supplementary $v \mathrm{~N}-\mathrm{H}$ and intramolecular hydrogen bonds $\mathrm{N}-\mathrm{H} . . . \mathrm{O}$. Then, the band assigned to $v \mathrm{~N}-\mathrm{H}, v \mathrm{C}-\mathrm{H}(\mathrm{CH} 2)$ appear from $3274-2500 \mathrm{~cm}^{-1}$. vasCOO- appear from $1617-1500 \mathrm{~cm}^{-1}$ while $v \mathrm{SCOO}^{-}$in the range of $1388-1293 \mathrm{~cm}^{-1}$. The vibration band at $1400 \mathrm{~cm}^{-1}$ is attributed to $v \mathrm{C}=\mathrm{S}$. The ones at 1054 and $760 \mathrm{~cm}^{-1}$ are respectively assigned to $\mathrm{vC}-\mathrm{N}$ and $\mathrm{vC}-\mathrm{C}$.

The results of the FT-IR measurements for both compound (1) and (2) agree with the crystal structure determined by single crystal X-ray diffraction by confirming the presence of the cation, the anion and strong intramolecular hydrogen bonds N-H...O.

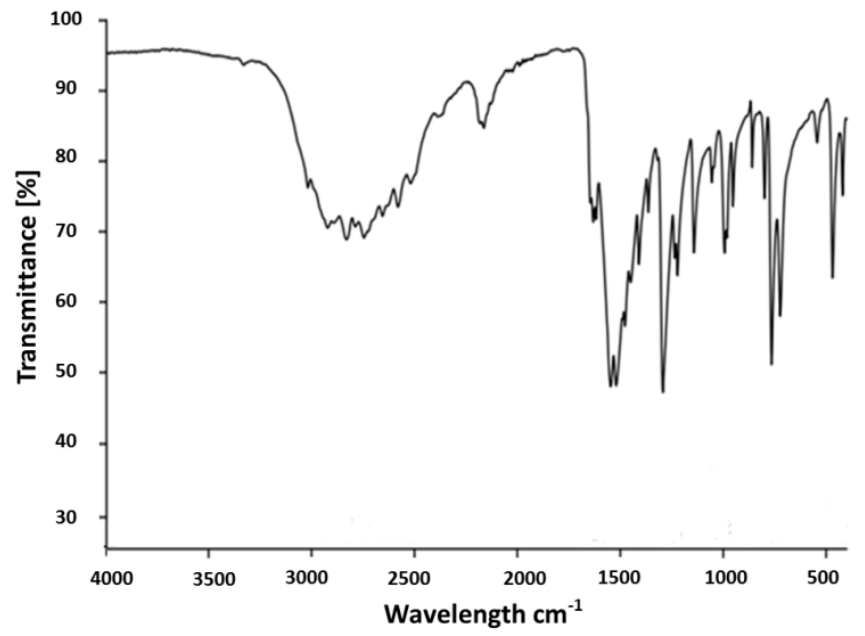

Fig. 5. FT-IR spectrum of 1,3 propanediamonnium oxalate.

Table 2. Assignment of the FT-IR bands of compound (1).

$\begin{array}{ll}\mathbf{v}(\mathbf{c m}-1) & \text { Assignments } \\ 3018-2519 & v \mathrm{~N}-\mathrm{H} ; \mathrm{vC}-\mathrm{H}\left(\mathrm{CH}_{2}\right) \\ 1631,1618,1546,1520 & \text { vasCOO } \\ 1293,1222 & v \mathrm{COO}^{-} \\ 1055 & v \mathrm{C}-\mathrm{N} \\ 765 & v \mathrm{C}-\mathrm{C}\end{array}$

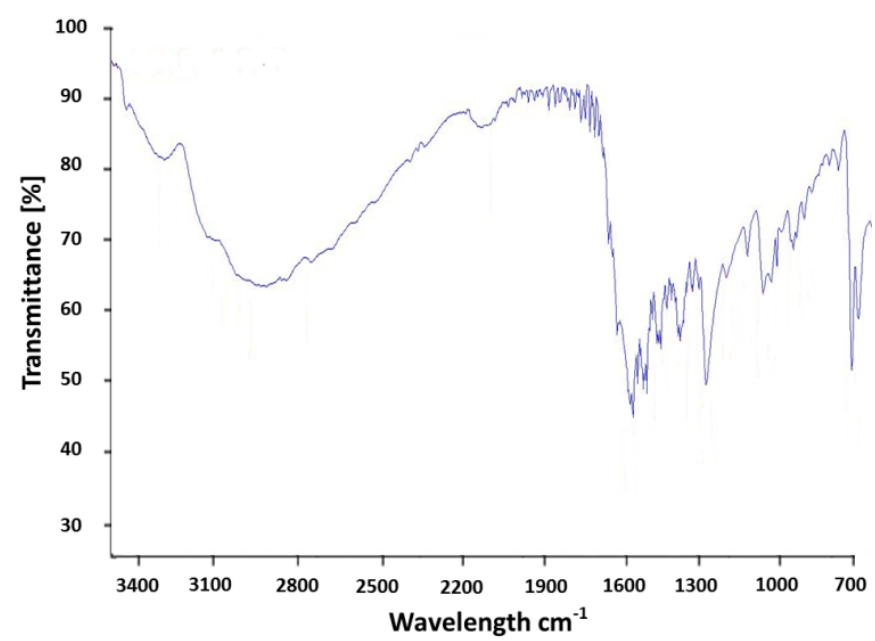

Fig. 6. FT-IR spectrum of 1, 3 propanediamonnium oxalate with incorporated thiourea.

Table 3. Asignment of the FT-IR bands of compound (2)

\begin{tabular}{ll}
$\mathbf{v ( c m - 1 )}$ & Assignments \\
\hline $3274-2500$ & $v \mathrm{~N}-\mathrm{H} ; \mathrm{vC}-\mathrm{H}\left(\mathrm{CH}_{2}\right)$ \\
$1617,1570,1522,1500$, & $v a s \mathrm{COO}^{-}$ \\
1388,1293 & $v \mathrm{SCOO}^{-}$ \\
1400 & $v \mathrm{C}=\mathrm{S}$ \\
1054 & $v \mathrm{C}-\mathrm{N}$ \\
760 & $v \mathrm{C}-\mathrm{C}$
\end{tabular}

\subsection{UV-Visible absorption}

Diffuse reflectance (Fig. 7) shows absorption from 250 to $400 \mathrm{~nm}$ for the salt (compound 1). This UV absorption may be assigned to $\pi-\pi^{*}$ and $n-\pi^{*}$ transition in oxalate ion. HOMO -LUMO energy gap of oxalic acid was already calculated in the literature to be $5.74 \mathrm{eV}(\lambda=343 \mathrm{~nm})$ [37]. It was shown that after co-crystalization of oxalic acid with the 2-(benzylamino) pyridine $(\mathrm{HOMO}-\mathrm{LUMO}$ energy gap $=6.66 \mathrm{eV})$, the resulting material had a significantly reduced energy gap $3.47 \mathrm{eV}(\lambda=572 \mathrm{~nm})$ [37]. The same phenomenon was observed by Faizan et al. [34] for another dicarboxilate salt: they observed that the HOMO-LUMO energy gap for the resulting salt was significantly lowered than its constituents; they concluded that this reduction may be due to the proton transfer process $\left(\mathrm{N}^{+}-\mathrm{H} \ldots \mathrm{O}^{-}\right)$and hydrogen bond formations. This may explain why the absorption of our material is extended below $400 \mathrm{~nm}$.

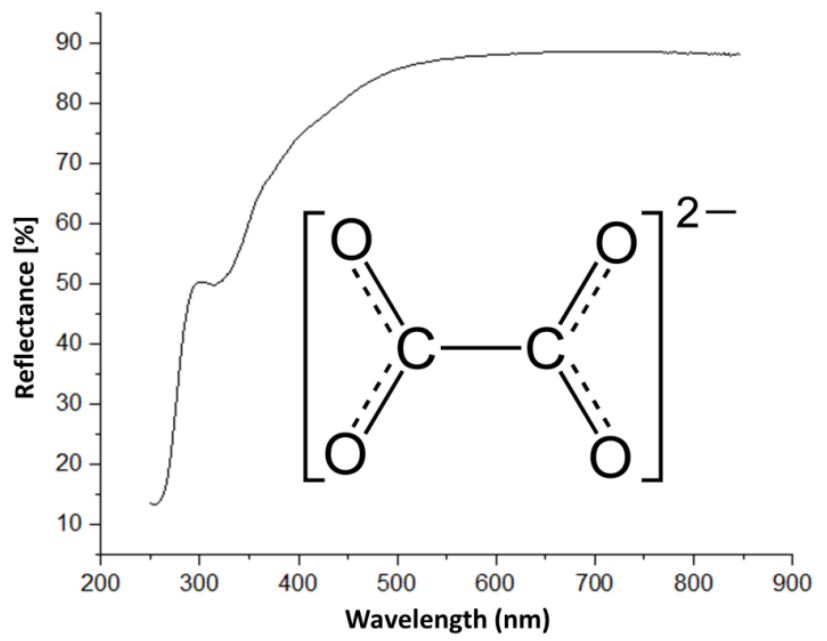

Fig. 7. UV-VIS Reflection spectrum of compound (1).

\subsection{Luminescence properties}

The emission spectra of oxalate ion via UV region excitation were earlier shown in the literature to be around $470 \mathrm{~nm}$ [2, 3, 38, 39]. The presence of $\sigma$ bond and especially delocalized $\pi$ bond are responsible for the excitation of oxalate ion in UV region [3]. The mapping photoluminescence of the compound (1) was performed with excitation from 250 to $360 \mathrm{~nm}$ and emission from 380 to $700 \mathrm{~nm}$. As shown in Fig. 8, the PL mapping exhibits a broad emission centered at $470 \mathrm{~nm}$. According to the literature [2;3], this excitation may be attributed to the oxalate ion, the unique optical center of 
the material. Owing to the absence of oxidizing agent in our compound, photochemical decomposition such as the one reported by Vitz [40] is unlikely to be responsible of the luminescence". The photoluminescence of the resulting material in which thiourea is incorporated was also investigated. The later material showed similar blue photoluminescence (Figure S1). A slight decrease of the emission intensity was observed. This decrease would originate from the difference of concentration of oxalate (the luminescent centers) which is higher in (1) than in (2).

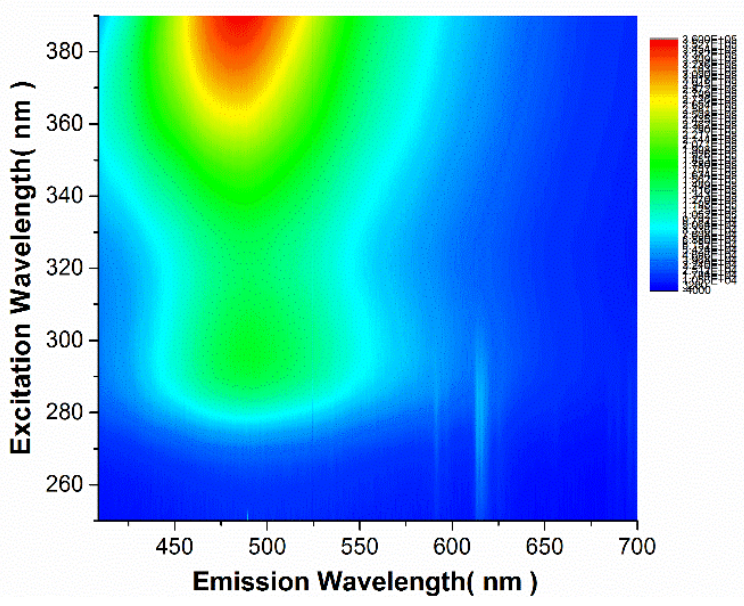

Fig. 8. PL mapping of the compound (1).

\section{Conclusion}

A new compound 1, 3 propanediaminium oxalate was synthesized at room temperature by mixing, in distilled water, dihydrated oxalic acid and 1,3 propanediamine in 1/1 molar ratio. The material is blue luminescent and consists of tridimensional network owing to strong $\mathrm{N}-\mathrm{H}^{\cdots \cdots \cdots \cdots} \mathrm{O}$ hydrogen bonds. An investigation on possible incorporation of thiourea in this later material was carried out successfully. Thus, we believe the incorporation of this molecule into a photoluminescent material may be useful for its future detection.

\section{References}

[1] K. Shimizu, Electroluminescence of Al/anodic alumina/electrolyte system and non destructive electronic avalanche, Electrochim. Acta 23 (1978) 295-298.

[2] T. Gao, G. W. Meng, L. D. Zhang, Origin of the Blue Luminescence in Porous Anodic Alumina Films Formed in Oxalic Acid Solutions, Chinese Phys. Lett. 20 (2003) $713-716$.

[3] D. Losic, A. Santos, Electrochemically Engineered Nanoporous Materials: Methods, Properties and applications, Springer International Publishing Switzerland 220 (2015) 238.

[4] Z. Chen, L. Sun, A. Luo, Y. He, Y. Zhang, Y. Li, Photoluminescent materials for highly toxic metals sensing: From downconversion to upconversion, Trends in Environmental, Analytical Chemistry 6 (2015) 1-9.

[5] T. Fei, K. Jiang, T. Zhang, Highly sensitive TNT photoluminescent sensing by a phosphorescent complex, Sensors and Actuators B 199 (2014) 148-153.

[6] Z. Xu, S. K. Kim, J. Yoon, Revisit to imidazolium receptors for the recognition of anions: highlighted research during 2006-2009, Chem. Soc. Rev. 39 (2010) 1457-1466.
[7] J. R. Jadhav, C. Bae, H. S. Kim, Fluorescence sensing of $\mathrm{H}_{2} \mathrm{PO}_{4}^{-}$by a imidazoliumbased cholestane receptor, Tetrahedron Letters 52 (2011) 1623-1627.

[8] J. Y. Lee, E. J. Cho, S. Mukamel, K. C. Nam, Efficient Fluoride-Selective Fluorescent Host: Experiment and Theory, J. Org. Chem. 69 (2004) 943-950.

[9] R. Z. Wu, X. Yang, L. W. Zhang, P. P. Zhou, Luminescent lanthanide metal-organic frameworks for chemical sensing and toxic anion detection, Dalton Trans. 30 (2017) 9859-9867.

[10] WHO, Internatinal Programme on Chemical Safety; Concise International Chemical Assessment Document 49 Thiourea, World Health Organization Geneva (2003).

[11] L. P Duan, J. Xue, L. L Xu, H. B. Zhang, Synthesis 1-acyl-3-(2'-aminophenyl) thioureas as antiintestinal nematode prodrugs, Molecules 15 (2010) 6941-6947.

[12] Z. M. Zhong, R. Xing, S. Liu, L. Wang, S. B. Cai, P. C. Li, Synthesis of acyl thiourea derivatives of chitosan and their antimicrobial activities in vitro, Carbohydr. Res. 343 (2008) 566-570.

[13] Z. Y. Wang, S.Wang, X. J Song, Y. G.Wang, Synthesis and biological activity of N-5-(1-o-chlorophenoxyethy1)-1,3,4-thiodiazol-2-y1]-N-aryloxyacetyl thioureas, Chin. J. Pestic. Sci. 7 (2005) 282-284.

[14] A. R. Sudzhaev, I. A. Rzaeva, R. A. Nadzhafova, Y. S. Safarov, M. A. Allakhverdiev, Antioxidant Properties of Some Thiourea Derivatives, Russian J. of applied chem. 84 (2011) 1329-1332.

[15] H. J. Bowley, E. A. Crathorne, D. L. Gerrard, Quantitative determination of thiourea in aqueous solution in the presence of sulphur dioxide by Raman spectroscopy, Analyst 111 (1986) 539-542.

[16] S. Abbasi, H. Khani, L. Hosseinzadeha, Z. Safari, Determination of thiourea in fruit juice by a kinetic spectrophotometric method, Journal of Hazardous Materials 174 (2010) 257-262.

[17] D. Amin, Determination of thiourea, phenylthiourea and allythiourea with iodine, Analyst 110 (1985) 215-216.

[18] H. Xiao-Lan, L. Hui-Tai, W. Hui-Qin, C. Wen-Rui, Z. Zhi-Fei, H. Fang, L. XiaoShan, Z. Zhi-Xin, Determination of Thiourea in Noodle and Rice Flour by Liquid Chromatography-Mass Spectrometry, Chinese J. Anal. Chem. 37 (2009) 1531-1534.

[19] A. Levent, E. Keskin, Y. Yardım, Z. Senturk, Electrooxidation of thiourea and its square-wave voltammetric determination using pencil graphite electrode, Rev. Anal. Chem. 30 (2011) 45-51.

[20] N. Spataru, T. Sparatu, A. Fujishima, Voltammetric Determination of Thiourea at Conductive Diamond Electrodes, Electroanalysis 17 (2005) 800 - 805.

[21] F. Manea, C. Radovan, J. Schoonman, Amperometric determination of thiourea in alkaline media on a copper oxide-copper electrode, J. Appl. Electrochem. 36 (2006) 1075-1081.

[22] L. Tian, Y. Gao, L. Li, W. Wu, D. Sun, J. Lu, T. Li, Determination of thiourea using a carbon paste electrode decorated with copper oxide nanoparticles, Microchim. Acta 180 (2013) 607-612.

[23] D. Nematollahi, M. Rafiee, Catalytic Oxidation of Thiourea at Alumina Modified Pt Electrode, Sensors 3 (2003) 534-543.

[24] N. Radic, J. Komljenovic, Potentiometric determination of mercury (II) and thiourea in strong acid solution using an ion-selective electrode with AgI-based membrane hydrophobised by PTFE, Fresenius J. Anal. Chem. 341 (1991) 592-596.

[25] M. A. Chamjangali, N. Goudarzi, A. G. Moghadam, A. H. Amin, An on-line spectrophotometric determination of trace amounts of thiourea in tap water, orange juice, and orange peel samples using multi-channel flow injection analysis, Molecular and Biomolecular Spectroscopy 149 (2015) 580-587.

[26] C. H. Görbitz, What is the best crystal size for collection of X-ray data? Refinement of the structure of of glycyl-L-serine based on data from a very large crystal, Acta Cryst. B55 (1999) 1090-1098.

[27] Z. Otwinowski, W. Minor "Denzo \& Scalepack". International Tables for Crystallography Volume F: Macromolecular Crystallography (1997). 
[28] R. I. Cooper, A. L. Thompson, D. J. Watkin, Crystals Enhancements: Dealing with Hydrogen Atoms in Refinement, J. Appl. Cryst. 43 (2010) 1100-1107.

[29] A. Altomare, M. C. Burla, M. Camalli, G. L. Cascarano, C. Giacovazzo, A. Guagliardi, A. Grazia, G. Moliterni, G. Polidori, R. Spagna, SIR97: a new tool for crystal structure determination and refinement, J. App. Cryst. 32 (1999) 115-119.

[30] P. W. Betteridge, J. R. Carruthers, R. I. Cooper, K. Prout, D. J. Watkin, Crystals Version 12: Software for Guided Crystal Structure, J. Appl. Cryst. 36 (2003) 1487.

[31] D. J. Watkin, C. K. Prout, L. J. Pearce, CAMERON, Chemical Crystallography Laboratory, Oxford, UK. (1996).

[32] FT-IR Spectroscopy-Attenuated Total Reflectance (ATR). Perkin Elmer Life and Analytical Sciences (2005).

[33]F. Ma, A. Huang, Rapid identification and quantification three chicken-wing woods of Millettia leucantha, Millettia laurentii and Cassia siamea by FT-IR and 2DCOS-IR Journal of Molecular Structure 1166 (2018) 164-168.

[34] M. Faizan, Z. Afroz, M. J. Alam, V. H. Rodrigues, S. Ahmad, A. Ahmad, Structural, vibrational and electronic absorption characteristics of the monohydrate organic salt of 2-amino-5-bromo-6-methyl-4-pyrimidinol and 2,3-pyrazinedicarboxylic acid: A combined experimental and computational study, Journal of Molecular Structure 1117 (2019) 229-241.
[35] N. Puviarasan, V. Arjunan, S. Mohan, FT-IR and FT-Raman Studies on 3Aminophthalhydrazide and N-Aminophthalimide Turk. J. Chem. 26 (2002) 323 333.[36] N. Sivakumar, N. Kanagathara, M. K. Marchewka, M. Drozd, R. Jayavel, G. Anbalagan, The theoretical and experimental vibrational studies of thiourea and silver nitrate (2:1) complex, Spectrochimica Acta Part A: Molecular and Biomolecular Spectroscopy 204 (2018) 717-725.

[37] M. Sangeetha, R. Mathammal, Establishment of the structural and enhanced physicochemical properties of the cocrystal-2-benzyl amino pyridine with oxalic acid, Journal of Molecular Structure 1143 (2017) 192-203.

[38] I. Vrublesky, A. Jagminas, S. Hemeltjen, W.A. Goedel, Effect of heat treatment on the structure of incorporated oxalate species and photoluminescent properties of porous alumina films formed in oxalic acid. Applied Surface Science 254 (2008) 7326-7330.

[39] Z. Li, K. Huang, Blue luminescence in porous alumina films, Phys.: Condens. Matter 19 (2007) 1-7.

[40] E. W. Vitz, The ferrioxalate actinometer: A lecture demonstration, J. Chem. Educ., 58 (1981) 655. 